\title{
Scottish Theology and the church and theology in Japan
}

\section{Masaichi Takemori}

Which foreign theologian is most widely read among Japanese Christians? It is usually believed that Calvin is read constantly and Barth is still very popular among the ministers and laity in this country. But there is another theologian, who may not be highly esteemed by theologians, but who, I suppose, is most widely read by Japanese Christians. This is William Barclay, professor of the New Testament at the University of Glasgow. That shows the strong influence which Scottish theology has on the Japanese church.

The most popular identification of Scottish theology is given Scottish theologians when they say "Theology is created in Germany, corrected in Scotland, and corrupted in America". Scottish theolgians admit the originality of German theology, but they also criticise German theology in that the Germans treat all the problems radically, and push through with only one idea, whereas the Scots adapt theology to the real situation of the church and human life. The Scots always want to be rational, while the Germans want to be logical. To the Scots, theology should not be abstract, but serve the actual life of the church. We must remeber that the primary purpose of the Gifford Lectures is to promote natural theology. Scottish theology is philosophical, practical and ecclesiastical.

The history of the Scottish mission in Japan is not long. The United Presbyterian Church sent her first missionary, Neobald A. Palm in 1874 to the Niigata district, followed by Hugh Waddel, Robert Davidson, and Henry Faulds. They esta- 
blished churches in the districts of Niigata and Tokyo. But their activities lasted only for 28 years, when their church in Scotland ceased to send missionaries.

The Ministers of the Nihon-Kirisuto Kyokai, the former presbyterian church of Japan, loved to read Scottish theology, because the Nihon-Kirisuto Kōkai, "The Catholic church in Japan" her antecedent was "reformed", although they professed to be interdenominational. So her ministers used to read the Scottish theologians from the earliest period in order to learn about the reformed faith and presbyterianism. James Denney and P.T. Forsyth were their favourite authors. For instance, "The Death of Christ" of Denney was read by most of the ministers of the church. Scottish theology exerted great influence to such representative theologians as Profs. Hidenobu $\mathrm{Ku}$ wada and Yoshitaka Kumano. When the theology of Karl Barth was introduced to this country, it found a very rich soil, well prepared by P.T. Forsyth, who is said to be "The Barth before Barth". "The Rule of Faith" of W. P. Paterson was used as a text book in the class of Prof. Kuwada. Many ministers were subscribers to "The Expository Times". Masahisa Uemura, the great leader of the church loved Scottish theology, and his daughter went to New College, Edinburgh University, in order to succeed to her father's work after his death. Tokutaro Takakura, Uemura's student and a theological leader, also studied in Edinburgh. Thus the solid way of theological thinking which has much interest in christology, soteriology and ecclesiology, became the very foundation of theology and the church in Japan.

Sound theological thinking based on well-ordered church life is the treasure which the church in Japan has inherited from Scottish theology. 